\title{
The Agricultural Co-operatives in China
}

\author{
Zhilu Zhang \\ School of International Business, Southwestern University of Finance and Economics \\ Chengdu 611130, China \\ E-mail: zhang.zhilu@gmail.com \\ Xinyu Zhang \& Yitao Huang \\ The School of Public Administration, Southwestern University of Finance and Economics \\ Chengdu 611130, China
}

\begin{abstract}
Along with China's renascent way, there are some obstacles blocking the way to achieve the development goal, especially the problems in rural areas. From the reality of our country, the experiences of other countries, and the plan for our whole nation, we can come to the conclusion that the agricultural co-operatives is the key to solve the problems and realize our goal.
\end{abstract}

Keywords: Institutional economics, Development, The agriculture co-operatives

\section{The extreme need of the Agricultural Co-operative system}

\subsection{China's remarkable development and the role of agriculture}

The past few years have witnessed a remarkable development in our country. During the 20-odd almost thirty years since China's reform and opening to the outside world, income level of the Chinese people has been ever increasing and our personal assets have been continually growing. Houses, cars, computers, stock and travelling abroad have become the main contents of the people's investments or consumption in the daily life. In 2003, China's gross domestic product (GDP) of the year topped the 10 trillion Yuan level to reach 11,689.8 billion Yuan, up by 7\% over the previous year at comparable prices. China became world's third largest economy in 2007. What is more, by the year 2020, the U.S. National Intelligence Council predicts, China will be an economic powerhouse, vying with the United States for global supremacy.

Learning from the history and reality, we can find that agriculture is the very base of a nation; agriculture feeds its people, and agriculture counts most when we talk about the stability of a country. By comparing Indices of Gross Domestic Product in China Statistical Yearbook since new China, a rule stands out showing that the development of agriculture has something to do with the economic fluctuations cycles. That is, agriculture is crucial to the industrial growth, and even the whole economy (Lin and Zhang, 2001, p.50).

\subsection{Severe social problems in China}

The development of agriculture plays an important role in our bloomy economy. Nevertheless, there are problems blocking the way of its developing which we can never ignore. Quite a few exists in rural area, and we really need to do something to fix them. In this article, we will give a system, the agricultural co-operatives, to tell how this system to solve these problems. Let us think about that, what kind of problems are we facing to build the "well-off" society, especially in rural areas?

Problem No. 1: The income gap is becoming larger and larger. According to a report by the National Development and Reform Commission, China's economic growth has not reached all of its citizens, especially in rural areas. After rapid expansion since 2003, the income gap in China has reached the second most serious "Yellow Light" level in 2005, or alert level, says an article on state media. "Unless effective measures are taken, the gap may drift further to the dangerous 'Red Light' level in the next five years," says the article in Study Times, quoting from a research report of the Ministry of Labor and Social Security.

The widening income gap in China has become a focal issue in China and aroused the concern of foreign researchers, says the article in the Xinhua Newspaper of 2005, which is run by the Party School of the Communist Party of China Central Committee. It says the United Nations Development Program released statistics that show the Gini coefficient, a 
statistical measure of inequality in which zero expresses complete equality while one expresses complete inequality, has reached 0.45 in China; 20 percent of China's population at the poverty end accounts for only 4.7 percent of the total income or consumption; 20 percent of China's population at the affluence end accounts for 50 percent of the total income or consumption. The article says the income gap, which has exceeded reasonable limits, exhibits a further widening trend. If it continues this way for a long time, the phenomenon may give rise to various sorts of social instability. "It's worth noting that according to experience in many countries and regions, social contradictions will increase as per capita GDP grows from the 1,000 US dollar level to the 3,000 US dollar level. China is precisely in this period," says the article. "Decision makers should not turn a blind eye to the big income gap". Chinese economist Wu Jinlian said "inequality of opportunity" is the root cause of the income gap, and Zhou Xiaochuan, governor of the People's Bank of China, China's central bank, said efforts at facilitating urbanization and setting up a social security system were keys to narrowing the income gap.

Problem No. 2: Cultivable land is becoming increasingly insufficient. China has the largest population all over the world, and the number is still growing. Though its Area of Territory is 9,600,000 sq.km, its Area of Cultivable Land is 1,300,400 sq.km (China Statistical Yearbook of 2008), which is far from enough. According to statistics, China's average per capita amount of arable land is less than 1.5 acres, equaling to only one-fourth to one-third of the world average. What's worse, in the process of accelerating industrialization, which had been emphasized for a long time, our environment was damaged a lot, and some even could not be restored (Lin and Zhang, 2001, p.51). National Bureau of Statistics of China says that the net decrease of the arable land in the whole country during 1978 to 1998 is 4,419,000 hectares, reduced by 4.5 percent (Hu and Sun, 2003. p.161).

Problem No. 3: The utilization of cultivable land is low on average, to a certain extent, aggravating environmental problems. Famers are this kind of people who are directly connected with field and depending on field. For various reasons, most of them are not well educated. Not all of them know much about scientifical farming, and what they usually do is seeking for more land to farm starvingly, or over-use their fields for personal benefits blindly.

The Cultivable Land only occupies about 13.54 percent of our Total Land Area, and the rest is not fit for farming (China Statistical Yearbook of 2008). If the peasants change the rest into farming lands, no doubt that the environment will be badly damaged. No matter it is over-use their fields, or exploitation of new lands which is not for farming, our mother nature has lost a lot. The total soil erosion area is increasing, and most of the soil is from the cultivable land, though we are trying to control the situation. Grassland degradation problem is brought to us and growing more and more serious. Desertification is coming nearer and nearer by the speed of surpassing 1000 sq.km per year. We make little contribution to prevent ecosystems from damage and retrogression (Hu and Sun, 2003, p.162).

\subsection{The good examples}

From all the above, we may come up with this question, "Why should our country meet with all these kinds of problems while developing by leaps and bounds, but other developed countries' are not so obvious and severe?" Yes, maybe we can benefit from their experience. Let me take our neighbor----Japan for instance.

Agriculture of Japan used to be of low degree organizing character typically, with 1.47 hectares for per rural family, and 70 percent of farmers were not able to use their fields fully. This sort of organization was doomed to be abandoned in the process of agricultural commercialization. After the World War II, Japan has finished its agricultural modernization while developing to be the second-biggest economic powerhouse. Though many questions still exist, Japan has managed to shift agricultural disaster after war to a total new stage of agriculture's development, which is mechanized, technological, socialized. In this progress, specialized co-operative organizations are critical: it speeds up the march on agricultural developing way, and maintains its economic development bloomy and healthy.

The objective reality makes China and Japan have many things in common: with large population comparatively, their cultivable lands are in gravely shortage; the Chinese organizing degree in rural areas is relatively low with features of "dispersed, weak, small, and poor" (Hong and Yu, 2006, p.187), just like what Japan used to be; the development of both countries are taking off, but the income gap between urban area and rural area is bothering China, which also bothered Japan years ago; even the environmental issue are common in both of them. No doubt that Japan has set a really positive example of adopting the agricultural co-operatives to promote the degree of healthy development. Since the agricultural co-operative system is able to benefit Japanese, we may take the agricultural co-operative system into consideration as a means to settle the social problems and help the economy in our country develop healthily.

So, what is the agricultural co-operative system indeed? The agricultural co-operatives, is a co-operative organization among farmers. It is forming with the development of agricultural economy, and the consequence of farmers' stronger and stronger need for improving status in open market exchange. Farmers in the agricultural co-operatives, a new agricultural industrial organization, establish rules themselves, contribute their own money willingly, serve themselves, and form a democratic working environment. The co-operative economy can date back to over 150 years ago, and the Agricultural Co-operatives is well developed in the main capitalistic countries. We can say that The Agricultural 
Co-operatives is a key modality of modern agriculture. It is the modern corporate system of agriculture.

\section{The Agricultural Co-operative system in the early years of New China}

New China in the early years had set up the Agricultural Co-operative system. Although it failed eventually, we can learn many things from the failure.

\subsection{The background}

After the War Against Japanese Aggression and the War of Liberation., the People's Republic of China got stuck in impoverishment, underdevelopment, and ignorance. Besides, development of the commodity economy had been delayed for many years. What's more, China was peered and threatened by the imperialist powers while the political situation was not that stable at the same time. The situation then we were in was that both internal and external "troubles" existed. Under these circumstances, we set up the Agricultural Co-operative system following Soviet Union's methods (Xu, 1995, p.26).

The original wish was good, but we did not use it in a proper way, so it failed. During the mid- and late 20th century, guided by radical and erroneous ideas, the agricultural co-operative economy was by degrees starting from the mutual-aid teams and then the producers` elementary co-operatives, then the advanced co-operatives, and finally it was involved in the people's commune movement frantically, whose characteristic was "large in size and collective in nature". In this way, the cooperative economy deviated from its standards and expectations, going astray. The action led to the food and clothing problems in the poor areas, led to slackness for working, and even led to the doubt about socialism. It prevented the proceeding of our society to a certain extent.

\subsection{The experience can be learned}

Seeking for the reasons why the system failed, we can conclude in one sentence, that is, we did not conform to the laws governing the socio-economic development. Just like mentioned, the years when China had stepped the way of being independent not that long, almost everything needed to be reformed, and something was deeply rooted. The self-sufficient natural economy has come into being for over two thousand years. In these natural and traditional villages, peasants were accustomed to cling to old ideas, old life style and old farming mode. Just that life style made the peasants fatuous, weak, sick and selfish. To transform this kind of reality, the government then took economic measures as well as political strong measures. Accordingly, people then felt that they were chained from limbs to hearts. They did not know what to do, and their passion dimmed. This system was ultimately abandoned (Zhang, 1996, p.23-26).

The following few years, people were scared to recall the years when they were in the co-operative system, and they even did not want to talk about it. The days were just like a nightmare. But, we cannot always think in this way. Though we had tried this way, and it failed, we must summarize the experiences. It mainly because the backward state of our productive forces then was not fit for agricultural co-operatives. And we should always keep it in mind that before we set up a system, we have to follow the order of nature. What is the most important when we say that it is the right time to set up the agricultural co-operatives, is that productive forces now has significantly enhanced, and we have all the conditions to adopt the Agricultural Co-operative System. The fact is that the agricultural co-operatives is gradually well accepted.

\section{The current situation of the Agricultural Co-operative system}

\subsection{The commercial need of Agricultural Co-operative system}

The main situation of agricultural product selling is "one bucket of products is carried to market in hand; two buckets of products are carried to market on the shoulder; and more products can be given to the brokers who will come to collect them". Agricultural products enter markets through vendors, state-owned and collectivity-owned enterprises and agricultural market leaders. Vendors often squeeze prices and hurt farmers, especially when the prices are low, farmers' benefits will be greatly damaged. State-owned and collectivity-owned enterprises run at low efficiency and high costs. The buy-sell relationship between market leaders and farmers in fact shows the farmers' dependence on enterprises, which determines the inharmonious and asymmetric interests. There are no legal and regulated organization chain among farmers, enterprises and production base, so there are no interest communities that bear risks and participates interest together. As a result, farmers do not have stable income. In short, peasants can neither protect themselves in the market trade nor associate to compete fairly with other non-peasant economic organizations in the market economy without the organizations representing peasants' interests.

\subsection{The benefits and satisfactions}

What comforts us is that in the process of agricultural commercialization, more and more peasants are realizing that it is crucial to develop agricultural co-operative system, and establish economic co-operative organization, and in fact, these people do benefit (Hong and $\mathrm{Yu}, 2006$, p.188). 
In Xinxing, a county seat of Guangdong Province, there is a famous company named "Wenshi Food Aggregative Corporation". It used to be a hennery run by a local person. Since 1983, the peasants in that place have joined in that company, basing on the co-operative system, that is, the peasants are guided by the company, and the company and peasants should work together like a unit to face economic competitions. In the process of 10 years' developing, the small hennery in former days had changed into a large corporation engaged in many industries, such as agricultural production, scientific study, trading and so on. As shareholders, the peasants really have earned a lot. At present, the company has many filiales in or out form Guangdong Province, and the scale is still expanding. A good future can be expected (Luo, 2005, p.359).

\subsection{More and more participants}

Farmers, in growing numbers, are involved in the cooperative system, believing this system is capable to bring them benefits confirmedly. In the areas developed relatively early and good such as Shangzhi, Linkou and Mishan of Heilongjiang Province, many associations and organizations are integrating into new, large-scale economic co-operative organizations such as the Agricultural and By-product Selling Association. Generally speaking, in the thousands of peasant associations in Heilongjiang Province, although there are not many well-organized, well-functioned, and effective ones, they are attracting more and more peasants like snowballing, and impact more and more peasants and districts to associate to extend the market. Peasants often say "what to feed, what to grow and who to sell to, are up to the organization." The organization they are referring to is the peasant economic co-operative organization (Hong and Yu, 2006, p.190).

\subsection{The good impact on solving social problems}

By studying and analyzing the theories and examples of this system, we can obviously find that this kind of system is solving some problems which were mentioned in the beginning.

The agricultural co-operative system is trying to bridge the income gap. The income gap we talk about is the income gap between urban and rural areas. The developing pace is shooting ahead and income increase accordingly. However, it is the features, "dispersed, weak, small, and poor" that stop farmers from being rich in such an unparalleled developing environment. "Dispersed" means that the majority is single farmer production, and decentralized production and management. "Weak" means that there is lack of economic cooperative organization and service agencies; therefore, farmer's anti-risk ability is weak. "Small" means that single farmer's business is small in scale, production and sale volume. "Poor" means that peasants are deprived in economic strength, personal quality, and education and information degree (Hong and $\mathrm{Yu}, 2006, \mathrm{p}$.187). The adoption of the agricultural co-operatives can change these features. Once an economic cooperative organization is set up, the farmers will work together and face the competition from the outside world. To enhance their ability to reply to the competition, the farmers are needed to attend school. Accordingly, because they are united to an organization which is large and strong, they are not dispersed, weak, and small any more; because they are re-educated, they are not poor any more. So, if the features which block their way to be rich have been removed, their step towards relucent future will be much quicker. Therefore, the income gap is being bridged, and it is possible to realize the dreams of facilitating urbanization and setting up a social security system, and the "equality of opportunity" can be seen.

Problem No. 2, "cultivable land is becoming increasingly insufficient" and problem No. 3, "the utilization of cultivable land is low on average, to a certain extent, aggravating environmental problems", can be combine to one which concerns about increasing the efficiency and the effectiveness of producing. First of all, peasant organizations' principle of recognizing and respecting peasants' rights and wishes, motivate peasants' enthusiasm to work harder for themselves and for the organization. Secondly, agricultural co-operative organizations are able to adjust, organize and allocate technologies, information funds and lands, minimize production, management and circulation cost, and maximize economic effectiveness and peasant income (Hong and Yu, 2006, p.190). They will take the cost they will pay about entironmental demolishment into consideration. In this way, the lands are not that insufficient, and then the environmental problems will not be so severe. Thanks to the co-operative system, these problems can be dealt with.

\section{Actions government should take}

Quite a few people have seen the profit the agricultural co-operative system brought. The prospect of the agricultural co-operatives is brilliant, but we can never slacken our attention. We must keep in mind that organizing peasant is one of the important rural problems. Organizing peasant to product and enter the market is a crucial problem of rural economy. The $16^{\text {th }}$ Party Congress emphasized that we must improve the degree of organization in peasant's market entry, and reduce the income gap between urban and rural areas. President $\mathrm{Hu}$, on Central Rural Work Conference held in January 2003, stated that one outstanding point of deepening rural reform is to develop agricultural product industry association and professional co-operative organization, to establish and improve the agricultural socialization service system, and to increase the extent to which peasants enter the market. This means that increasing the organizing degree is a key to promote agricultural industrialization and deepening rural economic mechanism reform (Hong and Yu, 2006, 
p.187). Then, what should our government do?

First of all, promote, deepen and broaden the development of market economy in our country. It is the requirement of the agriculture's developing. Only in the market economy, can the farmers who are in this system make decision independently, and be motivated.

Secondly, increase the communication between the peasants and the government. Under the current market economy, because the macro management of rural economic organizations is gradually weakened, there is a shortage of peasant-government communication, and there are difficulties for peasants to get economic and market information diffused by the government. Then, it is a necessary for government to get closer to the peasants, to tell what they want know, and offer what they need (Hong and Yu, 2006, p.187).

Thirdly, constitute laws fitting for the operation of the co-operative system. The progress of this system calls for a law to protect the members' profit in the organization. If so, more and more people will be a member of it.

Fourthly, foster more people who have a good knowledge of cooperative economy, including the officers. We should pay more attention to the leaders of cooperative organizations. It is them that matters the prospect of the agricultural co-operatives.

These are the relative things about the agricultural co-operatives in our country. I believe this system will bring a lot benefit to our country, if we use it in a proper way, in a practicing but learning way. Let it expand through all the China where it fits, and let us pray for it, for the brilliant future.

\section{References}

Feng, Hong, \& Yu, Jialin. (2006). Consideration on the Organization of Peasant Market Entry. Chinese Journal of Northest Agricultural University, 3, 187-191.

$\mathrm{Hu}$, Hanhui, and Ning, Sun. (2003). Industry Analysis on Sustainable Development. Nanjing: Southeast University Press.

Income gap in China reaches alert level. (2005). [Online] Available: http://www.chinadaily.com.cn/english/doc/2005-09/20/content_479472.htm (16 Aug. 2008).

Income gap in China widens in first quarte. (2005). [Online] Available: http://www.chinadaily.com.cn/english/doc/2005-06/19/content_452636.htm (22 Jul. 2008).

Li, Yongtao, and Li, Dongming. (2005). The experience learned from Japanese Agricultural Co-operatives. [Online] Available: http://www.shac.gov.cn/hwzc/hygl/200508/t20050803_133581.htm (11 Nov. 2007).

Lin, Shanlang, and Zhang, Guo. (2001). China Development Report. Beijing: Chinese Academy of Social Sciences Press.

Luo, Biliang. (2005). New Institutional Economics. Taiyuan, Shanxi: the Economics Press.

Supersized! China's economy booms. (2005). [Online] Available: http://findarticles.com/p/articles/mi_m0EPF/is_18_104/ai_n9532753 (16 Aug. 2008).

The Theory of the Agricultural Co-operatives. (2006). [Online] Available: http://www.studa.net/Profession/060207/11560282.html. (21 Jan. 2008)

Xu, Jingyong.(1995). An Analysis of Lessons from China's Agricultural Co-operatives Movement. Jianghan Forum, 3, 26-30.

Zhang, Letian. (1996). The research of People's Commune System. Journal of East China University of Science and Technology, 12, 23-30. 